\title{
CYTOGENETIC CHANGES IN BONE MARROW AND FIBROBLAST CELLS OF BALB / C LABORATORY MICE INDUCED BY MESTRANOL
}

\author{
TEODOROVIĆ RADISLAVA
}

Faculty of Veterinary Medicine, Belgrade

(Received 27. January 2004)

In this work the genotoxic effects provoked by Mestranol, which belongs to the group of chemical rodenticide- chemosterilants, were examined as a function of dose (7,5, 15 and $30 \mathrm{mg} / \mathrm{kg}$ w.b./c.c.) and of time (10, 20 and 30 days or 3, 5 and 7 days for "in vivo" and "in vitro" conditions, respectively). The genotoxic effects were scored on the basis of numerical and structural aberrations in both bone marrow and fibroblast cells from BALB/C laboratory mice in comparison to control groups.

Increased doses of the preparation increased numerical aberrations in both bone marrow and fibroblast cells significantly $(p<0.01)$ so that the greatest changes were noticed after the treatment with $30 \mathrm{mg} / \mathrm{kg}$ w.b./c.c. Numerical aberrations showed no significant differences $(p<0.05)$ as a function of time. Also, the several times greater number of aneuploid cellss was significantly different $(p<0.01)$ compared to the number of polyploid cells

Greater values for structural aberrations were obtained not only after the treatment with the largest dose of $30 \mathrm{mg} / \mathrm{kg}$ w.b./c.c., but also after longer exposure times (i.e. for 30 or 5 days respectively). Statistically significant differences were found between the number of gaps, as well as fragments, in comparasion to the number of Robertsonian translocations $(p<0.01)$, while there were no significant differences between thenumber of gaps and fragments $(p>0.05)$.

Key words: cytogenetic changes, Mestranol, mouse, fibroblast, bone marrow cells.

\section{INTRODUCTION}

After several decades of application the use of earlier mechanical, physical, biological and chemical methods to eradicate rodents, no longer gives satisfactory results, especially of the application chemical preparations, because resistance occurrs of more and more frequently. For that reason a new group of chemical preparations was developed on the basis of chemosterilants, which induce temporary or permanent sterility (Eriksson et al., 1971). Chemosterilants can function at various stages of the reproductive cycle: at the gamete level, before or after fertilization, by preventing gamete implantation into the uterus by 
damaging the embryo during development orby inducing abortion (Jakson, 1959; Rex, 1970).

During the sixties Mestranol was introduced as a chemosterilant, as well as a standard for estrogenic steroids, and during the following decade many uses of this preparation were investigated in practice. It was found that a bait treated with Mestranol was very acceptable and that the most significant reduction of young animals, occurr in 82 days after a treatment of both sexes (Kincl and Dorfman, 1965; Marsh and Howard, 1969). In contrast to Mestranol, there are many chemosterilants which are unacceptable for rodents (Gao and Short, 1993).

Various chemical compounds, including rodenticides, can cause genotoxical changes- mutagenetic, cancerogenic and teratogenic (Irving, 1973; Soldatović, 1994; Stanimirović et al., 1996). Some anticoagulants like Antikolin, Rosol, Rakumin-57, can cause genotoxic changes both in harmful rodents and in other mammals (Soldatović et al., 1981, Kataranovski, 1986). Taking into consideration that there are very few data on the genotoxic effects of chemosterilants, the aim of this work was to determine the possible cytogenetic changes in cells of mice treated with Mestranol as a representative estrogenic preparation.

\section{MATERIAL AND METHODS}

\section{Chemosterilant}

The genotoxic effects of Mestranol (17 $\alpha$-ethinylestradiol-3-methilether) a highly efficient steroid chemosterilant, were investigated in vivo and vitro.

\section{Experimental design}

For the studies in vivo, the preparation was given orally by gastric tube to BALB/C mice in doses of 7,5, 15 and $30 \mathrm{mg} / \mathrm{kg}$ body mass. After 10, 20 and 30 days, bone marrow cells were examined for mitotic activity as well as numerical and structural aberrations. Chromosomal analyses were performed on cells fixed in Carnam solution and dissolved in $0,56 \% \mathrm{KCl}$ by the method described by $\mathrm{Hsu}$ and Patton (1969).

For the studies in vitro, mouse fibroblasts were treated with 7,5, 15 and 30 $\mathrm{mg}$ Mestranol per $\mathrm{kg}$ cell culture for 2, 3 and 5 days. Mitotic activity and the appearance of structural and numerical aberrations were investigated. Muscle tissue from neonatal BALB/C mice aged 2-3 days was taken and fibroblast cultures prepared by the method of Durtrillah and Couturier (1989) for determination of the karyiogram.

The cell preparations were stained for $5 \mathrm{~min}$ in Giemsa. Groups of seven sexually mature male animals were formed for each dose and exposure time, as well as for the control groups.

\section{Statistical analysis}

The results obtained were analyzed Student's test (The Statgraphics 5.0Statistical Graphics Corporation, USA programme). 


\section{RESULTS AND DISCUSSION}

From the results obtained (Table 1) concerning to the appearance of numerical aberrations in mouse bone marrow cells "in vivo" it is obvious that Mestranol induced numerical aberrations. The relative number of diploid cells in all the control groups was almost equally high $(98,33-100,00 \%)$, while single aneuploid cells were observed $(1,66 \%)$, in some control groups. In no animal from the control groups were polyploid cells recorded. Thus the maximal level of numerical aberrations in the control groups was $1.66 \%$, which can be tolerated, because a few may appear as a consequence of the methodology used.

With increased doses of the preparation, numerical aberrations in the bone marrow cells also increased, so that the greatest levels were noticed after treatment with $30 \mathrm{mg} / \mathrm{kg}$ w.b. This increased as a function of dose was statistically significant $(p<0.01)$. However, although polyploid cell number as a function in dose increased compared to the control groups $(p<0.01)$, the doses had no significant effect $(p>0.05)$ as a function of time, while, with regard to the number of aneuploid cells it was significantly lower $(p<0.01)$. Statistical analysis of the numerical aberrations as a function of time, showed no statistical significance $(p>0.05)$.

The numerical aberations, after Mestranol application "in vitro", in mice fibroblast cells are presented in Table 2. The diploid number of chromosomes in the control groups was $98,15-100,00 \%$, aneuploid ones maximally $1,85 \%$, while polyploid cells were not registered. Along with the increase of Mestranol dose the numerical aberrations also increased, so in all cases statistically significant differences from the values for the control groups $(p<0.01)$ were registered. Statistically significant differences $(p<0.01)$ were also found concerning the number of aneuploid cells in comparison to polyploid cells after all the applied doses. Significantly more $(p<0.01)$ aneuploid cells were recorded the doses of 15 and $30 \mathrm{mg} / \mathrm{kg} \mathrm{c.c.} \mathrm{than} \mathrm{with} \mathrm{the} \mathrm{smallest} \mathrm{dose} \mathrm{of} 7.5 \mathrm{mg} / \mathrm{kg}$ c.c., but between the two larger doses there were no statistically significant differences $(p>0.05)$. Concerning polyploidy in the fibroblast cells, statistically significant differences $(p<0.01)$ were detected only between the maximal dose $(30 \mathrm{mg} / \mathrm{kg} \mathrm{c.c})$, and lower doses (7,5 and $15 \mathrm{mg} / \mathrm{kg}$ c.c.) of chemosterilant.

The analyses of structural aberrations in mouse bone marrow and fibroblast cells as functions of time and dose are presented in Table 3 . About 100 metaphase figures were analysed in each group. In the control groups, just one gap, was found and there were no structural aberrations. Statistically significant differences in comparison to the control groups $(p<0.01)$ were evident for the groups treated with Mestranol. Structural aberrations were most numerous after the $30 \mathrm{mg} / \mathrm{kg}$ w.b./c.c. dose and after the longest exposures. Statistically significant differences $(p<0.01)$ were recorded between the $30 \mathrm{mg} / \mathrm{kg}$ w.b./c.c. and $7.5 \mathrm{mg} / \mathrm{kg}$ w.b./c.c. doses. Also statistically significant differences between the levels of gaps and fragments in comparison to Robertsonian translocations $(p<0.01)$, while the numbers of gaps and fragments were not significantly different $(p>0.05)$. 


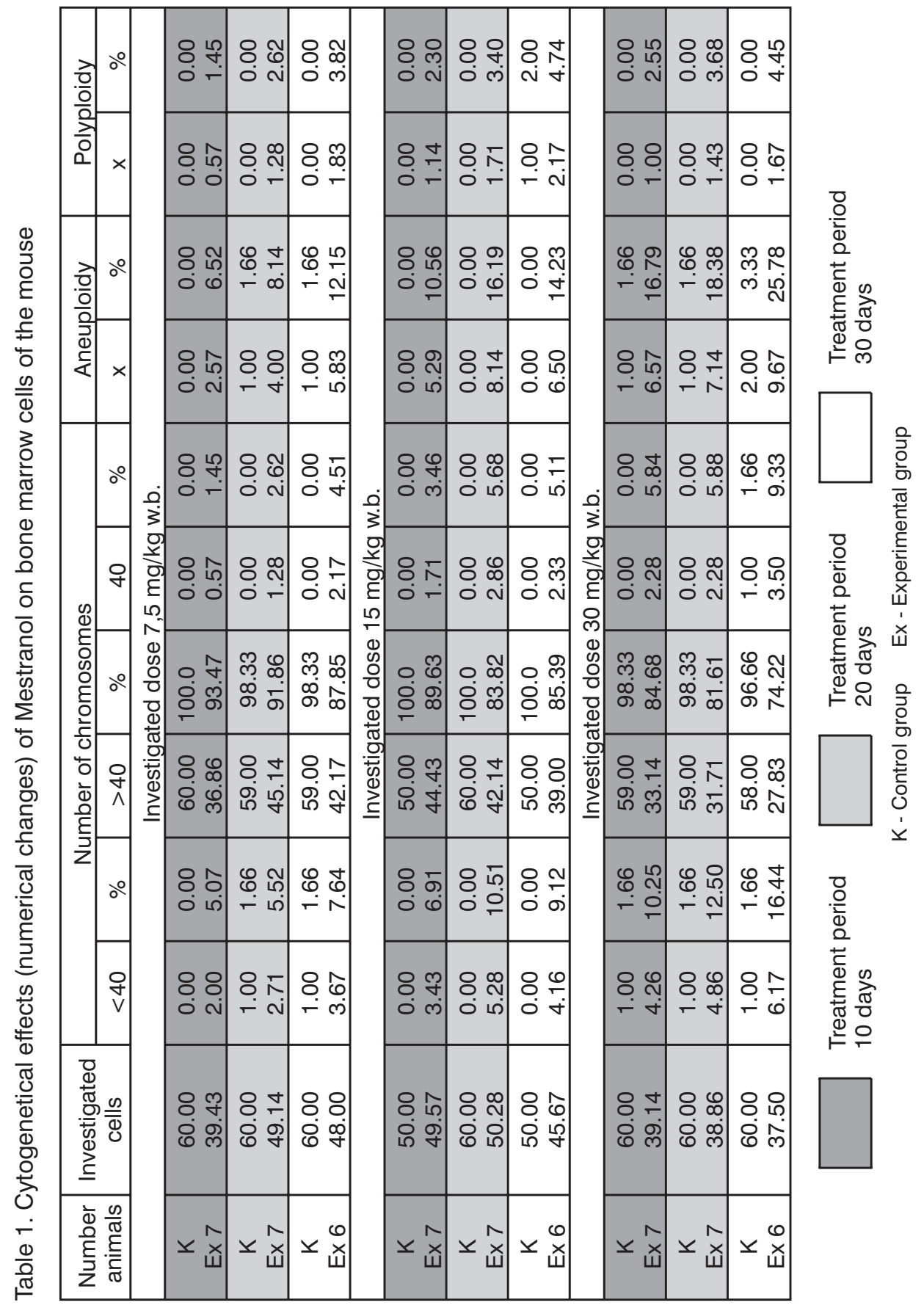




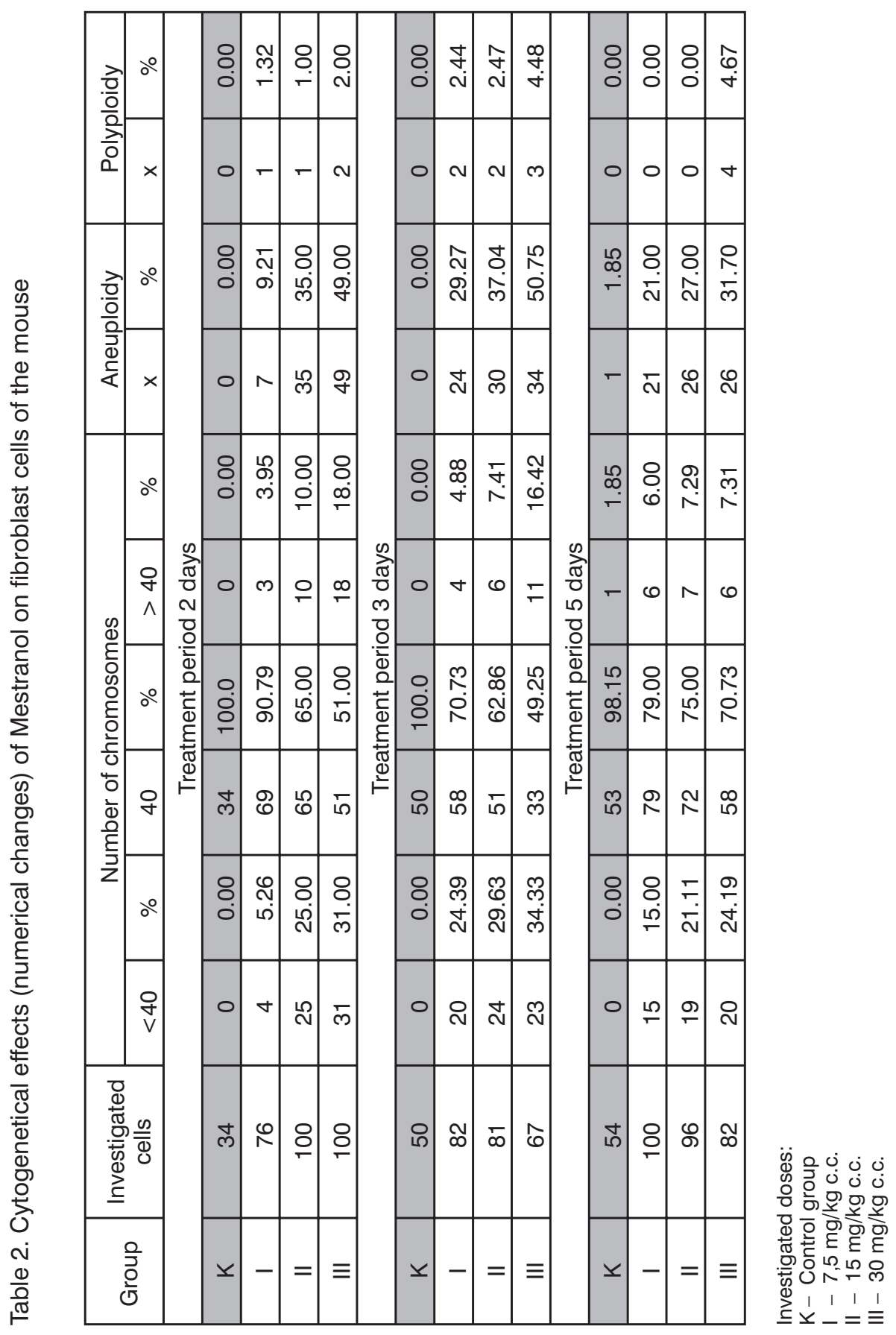


Table 3. Cytogenetical effects (structural changes) of Mestranol on bone marrow and fibroblast cells of the mouse

\begin{tabular}{|c|c|c|c|}
\hline \multirow[b]{2}{*}{ Group } & \multicolumn{3}{|c|}{ Structural changes (\%) } \\
\hline & Gaps & Fragments & $\begin{array}{l}\text { Robertson's } \\
\text { translocations }\end{array}$ \\
\hline \multicolumn{4}{|c|}{ Bone marrow cells } \\
\hline $\mathrm{K}$ & 0.00 & 0.00 & 0.00 \\
\hline 1 & 2.04 & 3.52 & 1.06 \\
\hline II & 4.06 & 6.50 & 2.02 \\
\hline III & 6.53 & 7.00 & 2.54 \\
\hline \multicolumn{4}{|c|}{ treatment period 20 days } \\
\hline $\mathrm{K}$ & 0.00 & 0.00 & 0.00 \\
\hline 1 & 6.54 & 8.50 & 3.06 \\
\hline II & 10.53 & 9.54 & 3.48 \\
\hline III & 11.98 & 9.47 & 6.50 \\
\hline \multicolumn{4}{|c|}{ treatment period 30 days } \\
\hline $\mathrm{K}$ & 0.00 & 0.00 & 0.00 \\
\hline 1 & 7.48 & 1.97 & 3.52 \\
\hline II & 8.96 & 12.51 & 4.47 \\
\hline III & 16.54 & 17.00 & 7.04 \\
\hline \multicolumn{4}{|c|}{ Fibroblast cells } \\
\hline K & 0.00 & 0.00 & 0.00 \\
\hline 1 & 3.01 & 5.48 & 1.04 \\
\hline II & 6.47 & 7.02 & 3.04 \\
\hline III & 8.02 & 7.47 & 4.48 \\
\hline \multicolumn{4}{|c|}{ treatment period 3 days } \\
\hline $\mathrm{K}$ & 0,00 & 0.00 & 0.00 \\
\hline I & 3.46 & 4.51 & 3.54 \\
\hline II & 7.49 & 8.50 & 6.53 \\
\hline III & 8.02 & 10.00 & 7.98 \\
\hline \multicolumn{4}{|c|}{ treatment period 5 days } \\
\hline $\mathrm{K}$ & 1.00 & 0.00 & 0.00 \\
\hline 1 & 6.47 & 8.00 & 5.52 \\
\hline II & 10.52 & 11.06 & 7.03 \\
\hline III & 16.53 & 17.04 & 10.54 \\
\hline
\end{tabular}

Investigated doses: I $-7,5 \mathrm{mg} / \mathrm{kg}$ w.b./c.c.

II $-15 \mathrm{mg} / \mathrm{kg}$ w.b./c.c.

III - $30 \mathrm{mg} / \mathrm{kg}$ w.b./c.c 
On the basis of these results, it is evident that Mestranol, applied in the examined doses for the investigated times, can alter genetic material. Cytogenetic changes were recorded for other rodenticides as well (chemosterilants and anticoagulant rodenticides) by many authors (Sofradžija et al, 1989; Kataranovski, 1994; Stanimirović et al, 1997; Teodorović et al, 1999). As a consequence of these genotoxic effects, as determined here for Mestranol, pregnancy disorders are possible resulting in abortion or the production of off spring with congenital malformations. This has already been found by several authors for a number of preparations (Elias et al., 1978; Brent, 1984; Hrgović et al., 1991).
Address for correspondence:
Dr Radislava Teodorović
Department of Zoohygiene,
Faculty of Veterinary Medicine,
University of Belgrade
Bul. JNA 18, 11000 Beograd,
Serbia \& Montenegro
E-mail: rada@vet.bg.ac.yu

\section{REFERENCES}

1. Brent RL, 1984, Ethical and legal implications of drug use in pregnancy. In: Drug Use in Pregnancy (Stern L.ed), ADIS Helth Science Press, Balgowlah, Australia, 1-11.

2. Dutrillaux B, Couturier J, 1989, Cit M Golubović, Uticaj Halotana na citogenetske promene kod stres osetljivih i stres otpornih svinja, Doktorska disertacija, Beograd, 1996.

3. Elias DJ, Thompson RD, Savarie PJ, 1978, Effects on the anticoagulant diphenadione on sucking calves, Bull Environm Contam Toxicol, 20, 71-6.

4. Eriksson RJ, Downing HE, Marsh RE, Howard WE, 1971, Wildlife Manag, 35, 573-6.

5. Gao Y, Short RV, 1993, The control of rodent populations, Oxford Rev Reprod Biol, 15, 265-310.

6. Hrgović N, Vukićević Z, Kataranovski D, 1991, Deratizacija i suzbijanje populacija štetnih glodara, Dečije novine, Gornji Milanovac.

7. Hsu TC, Patton Jl, 1969, Bone marow preparations for chromosome studies, In: Bemirschke K (Ed). Comparative mammalian cytogenetics, Springer Verlag, Berlin Heikdelberg New York, 454-60.

8. Irving CC, 1973, Interaction of chemical carcinogens with DNA, Meth Canc Res, 216-9.

9. Jackson H, 1959, Antifertility substances, Pharmacol Rev, 11, 135-72.

10. Kataranovski $D, 1994$, The toxicity of rodenticides in rats following topical application I LD 50 and LD100 values and changes of selected serum and urine biochemical parameters, $J$ Serb Chem Soc, 59, 787-95.

11. Kataranovski $D$, Kataranovski $M$, 1986, Efekti kumarinskih rodenticida na proliferaciju i varijabilnost humanih Thimocita, Zbornik radova, VII Kongres biologa jugoslavije, Budva, 320.

12. Kincl FA, Dorfman RI, 1965, Antifertility activity of various steroids in the female rat, $J$ Reprod Fert, 10,1,105-13.

13. Marsh RE, Howard WE, 1969, Evaluation of mestranol as a reproductive inhibitor of Norway rats in garbage dumps, Wildlife Manag, 33, 133-8.

14. Rex EM, 1970, Theory and potencial value of rodent chemosterilants, World Health Organisation, WHO/VBC/ 70. 176. 1- 4

15. Sofradžija A, Hadžiselimović R, Maslić E, 1989, Genotoksičnost pesticida, Svjetlost Sarajevo.

16. Soldatović B, 1994, Retrospektive razvoja citogenetike, Abstrakti - I kongres citogenetičara Srbije, 8-11 jun,Vrnjačka Banja, 1-2. 
17. Soldatović B, Zimonjić D, Haidovy MAN, Savić I, Kataranovski D, 1981, Mutageni efekti nekih rodenticida i insekticida konstatovani na ćelijama sisara, Zbornik radova IX Simpozijuma iz DDD i neškodljivog uklanjanja otpadne animalne tvari, Haludovo 32-37.

18. Stanimirović Z, Vučinić M, Soldatović B, Marković B, 1997, Genotoxicity and potential hemosterilant effects of Rodol, Acta Vet Beograd, 47, 237-46.

19. Stanimirović Z, Vučinić M, Fišter S, Bojkovski J, Vučićević M, 1996, Citogenetički monitoring u funkciji zaštite životne sredine, V Kongres ekologa Jugoslavije, Zbornik sažetaka 22-27 septembar, Beograd, 99.

20. Teodorović Radislava, Soldatović B, Teodorović V, Mirilović M, 1999, The genotoxic effects of alphachlorhydrin in BALB/C strain, Acta Vet Beograd, 49, $239-46$.

\title{
CITOGENETIČKE PROMENE ĆELIJA KOŠTANE SRŽI I FIBROBLASTA KOD LABORATORIJSKIH MIŠEVA SOJA BALB/C INDUKOVANE MESTRANOLOM
}

\author{
TEODOROVIĆ RADISLAVA
}

\section{SADRŽAJ}

U ovom radu su prikazani rezultati ispitivanja genotoksičnih efekata preparata "Mestranola", koji spada u grupu hemijskih rodenticida-hemosterilanata. Ispitivanja su izvršena u funkciji doze (7,5, 15 i $30 \mathrm{mg} / \mathrm{kg}$ w.b./c.c) i vremena $(10,20$ i 30 dana, odnosno 2, 3 i 5 dana) u uslovima in vivo i in vitro. Procena genotoksičnih efekata je vršena na osnovu numeričkih i strukturnih aberacija na ćelijama koštane srži i fibroblasta laboratorijskog miša soja BALB/C, u odnosu na kontrolne grupe.

Sa povećanjem doze preparata vrednost numeričkih aberacija, u ćelijama koštane srži i fibroblasta, je značajno $(p<0,01)$ rasla tako da su maksimalni nivoi zabeleženi posle tretmana u dozi od $30 \mathrm{mg} / \mathrm{kg}$ w.b., dok kod numeričkih aberacija u funkciji vremena nije utvrđena statistička značajnost $(p>0,05)$. Takođe su utvrđene statistički značajne razlike $(p<0,01)$ u pogledu višestruko većeg broja aneuploidnih ćelija u odnosu na poliploidne.

Maksimalne vrednosti strukturnih aberacija postignute su ne samo posle tretmana sa maksimalnom dozom od $30 \mathrm{mg} / \mathrm{kg}$ w.b./c.c., već i posle najdužih ekspozicija (30, odnosno 5 dana). Utvrđene su statistički značajne razlike između nivoa nastalih gapova, odnosno fragmenata u odnosu na Robertsonove translokacije $(p<0,01)$, dok u pogledu razlika nivoa nastalih gapova i fragmenata nisu utvrđene signifikantne razlike $(p>0,05)$. 